\title{
THE QUEST FOR COHERENCE IN EU CRISIS MANAGEMENT IN THE SOUTH CAUCASUS: THE CASE OF SOUTH OSSETIA
}

\author{
Irena Mnatsakanyan \\ Sapienza University of Rome, Department of Political Science \\ Rome, Italy \\ irena.mnats@gmail.com
}

\begin{abstract}
The paper assesses the EU crisis management in the South Caucasus with a particular focus on the South Ossetian conflict. The EU engagement in the South Caucasus dates back to 2003, when the region gained importance for the EU as an energy transportation corridor between East and West, as well as for security purposes, in terms of building "a new chain of friends" outside the EU borders. At the same time the EU introduced a wide range of institutional structures and coordination mechanisms over multiple policy domains of crisis management. In contrast, the increased EU presence in the region did not contribute to coherent crisis management in South Ossetia. The involvement of multiple institutional actors in the planning and implementation phases of CFSP and Development Aid has increased the institutional fragmentation within EU`s crisis management architecture creating a need to establish coherence in their actions.

The paper argues that the incoherence in EU crisis management is undermined by the overlapping mandates of EU institutional agents in the two main policy areas: the EU's Common Foreign Security Policy (CFSP) and Development Aid Policy (DAP).

The impact of the mandate overlaps on incoherence is empirically analysed through the prism of the bureaucratic politics theoretical framework.
\end{abstract}

\section{Keywords}

Coherence, European Union (EU), Frozen Conflicts, South Caucasus 


\section{INTRODUCTION}

The 2008 Russo-Georgian war and the sudden eruption of the violence in the Nagorno Karabakh conflict zone on April 1, 2016 reminded everybody that, contrary to widespread beliefs, the "frozen" conflicts in the South Caucasus are not, in fact, "frozen" and have unusual escalation patterns. In fact, when frozen, a conflict provides a false sense of security, as such a conflict can last years without open violence, but may easily turn into a violent conflict once triggered (Faber 2000). The term "frozen conflict" has been traditionally applied to the existing ethnic conflicts over the Black Sea- South Caucasus region (Nagle and Clancy 2009, 19). In all three cases: South Ossetia (1991-1992), Abkhazia (19921993), Nagorno-Karabakh (1988-1994), Transnistria (March 1992-July 1992), ceasefire agreements have been reached without final settlements, turning the Black Sea-South Caucasus region into an area with unresolved conflicts.

The freezing of Caucasian conflicts has been called "one of Europe's most important political innovations", but at the same time it indicates a failure to permanently settle these conflicts, and brings a risk to the security and stability of the European continent (Faber 2000).

Georgia with its strategic economic and geographic location is an important transit country for the diversification of energy supplies to Europe (EEAS 2004, 11). The EU`s energy diversification in light of its dependency on Russian gas, is high on the EU's political agenda and is one of the priorities of the President of the European Commission (European Movement International 2016, 2).

In order to reduce its dependency on Russia the EU has long sought alternate energy supply routes, including the Trans-Anatolian Gas Pipeline Project (TANAP), Nabucco, White Stream(that connects to the Bulgaria-RomaniaHungary-Austria (BRUA) pipeline) and Azerbaijan-Georgia-Romania Interconnector (AGRI) pipelines, which aim to bring the Caspian gas through Azerbaijan and Georgia to Europe by passing Russia( Kakachia 2011,1). However, the escalations of the conflicts over South Ossetia and Abkhazia in 2004 and 2006, as well as the sudden outbreak of the August war between Russia and Georgia, demonstrated significant risks associated with the operation of the 
energy transit corridor in the region (Kakachia 2011,1). It also demonstrated the need for broader security guarantees for the region, which is vital to European energy security.

In this context, the EU engagement in the Southern Caucasus deserves a particular attention as it shows the significance of the frozen conflicts for the EU. In response to the escalations of the Caucasian conflicts, the EU expanded its presence in the South Caucasus via introducing new crisis management instruments in the region. During the war of August 2008, the EU led the mediation between Georgia and South Ossetia under the presidency of Sarkozy, by establishing a ceasefire agreement. Another serious step from the EU was the rapid deployment of EU civilian Monitoring Mission (EUMM) in Georgia, with a mandate of monitoring the effective implementation of the ceasefire agreement in the whole territory of Georgia, including South Ossetia (EEAS 2010). Meanwhile, the EU introduced the mandate of the EU Special Representative to the South Caucasus, Civilian Planning Conduct Capability (CPCC) and Crisis Response and Operational Coordination (CROC) units which were supposed to coordinate the EU responses to external conflicts in the planning and implementation phases of crisis management. However, the EU was unable to use the variety of its crisis management instruments in a coherent manner in South Ossetia. The diversity of institutional actors involved in the same policy area with inter-related mandates and the divergence of their interests have increased the risk for policy fragmentation and incoherent outcomes within the EU`s institutional machinery (Post 2013, 67).

The expected empirical results aim to identify the overlaps of institutional mandates in South Ossetia and their impact on the coherence of EU crisis decision making process at the planning and implementation levels. The paper concludes giving recommendations on how the EU can improve the interinstitutional coherence in the future. 


\section{THE RELEVANCE OF “COHERENCE" IN THE TREATIES}

Achieving coherence in EU external relations has been heightened since the establishment of the Single European Act (SEA), when Community external action was expanding and European Political Cooperation (EPC) was institutionalized (Cremona 2011, 55). The EU Presidency and the Commission were mandated to ensure the coherence between the EPC and the EC. In transforming the EPC into the CFSP the Treaty on European Union reiterated the need for coherence between the CFSP and the external policies of the Community, linking it to the single institutional framework and imposing a duty on the Council and Commission to ensure coherence specifically in relation to EU external activities (Cremona 2011, 55-57).

The original Maastricht version of the Treaty on European Union emphasized towards the need for a greater coherence in the Union`s external relations (TEU Article C). The Treaty mentioned that the Council and the Commission shall be responsible for ensuring coherence, each in accordance with their respective powers.

Meanwhile, under the Amsterdam Treaty, the Council Secretariat delivered a reference framework for the coherent management of "any crisis the Union might have to face", stating that a coherent framework needs to be established in which the instruments from the three pillars and the mandates of different institutions should be implemented in synergy (Gebhard 2008, 12).

The Treaty of Amsterdam introduced the mandate of a High Representative (HR), which potentially constituted a key instrument for the improvement of inter-institutional coherence (Portela and Raube 2012, 8). The HR was meant to represent the Union externally in subordination to the Presidency, which already had to share its external representation functions with the Commission in accordance with the Article 18 (3) of the Amsterdam Treaty (Portela and Raube 2012,8). However, such an arrangement complicated the question of the external representation of the Union as it added to the multiplicity of actors involved in it rather than reducing it (Portela and Raube 2012, 8). 
The issue of coherence in the specific context of crisis management gained a considerable momentum when the Nice Treaty saw the addition of the European Security and Defense Policy (ESDP) (Gebhard 2008, 5). The creation of ESDP produced further challenges to coherence and highlighted the need for an enhanced cooperation at EU and national levels (Duke 2011). The central focus of ESDP was initially on the military dimensions of crisis management, largely due to successive shocks in the Western Balkans, but this was soon complicated by the growing attention being paid to civilian aspects of crisis management where the question of inter-pillar competences became more acute (Duke 2011). The latter has raised a new question of 'mandate' allocation' or who should be responsible for what, within the Community and CFSP pillars (Nuttall 2001).

The need for the coherence in EU crisis management was further underlined by the adoption of the Lisbon Treaty, which in contrast to Maastricht, Amsterdam and Nice treaties introduced several institutional reforms to improve the coherence in EU crisis management (Blockmans and Wessel 2009).

The position of the HR of the Union for Foreign Affairs and Security Policy/ Vice President of the European Commission and European External Action Service (EEAS) was aimed to ensure coherence between between the different areas of EU external action (Lisbon Treaty, Article 21).

From coherence perspective, such an arrangement was supposed to overcome the division between the external competencies of the Council and the Commission, but the fact that the Lisbon Treaty has granted a coordinating role not just to the HR, but to several actors has made the quest for coherence in EU crisis management more challenging than it was before.

\section{DEFINING “COHERENCE"}

In this paper coherence is defined as the degree to which EU supranational institutions operate as a coordinated process of decision making at the planning and implementation levels of crisis management (Christiansen 2001).

This definition is in line with the research goal of the paper as it looks at the interaction between multiple institutions with coordination being an important 
instrument for decision making. It applies coherence as a political objective of inter-institutional cooperation, while coordination as an instrument to achieve this objective. Thus, it also enables one to apply coordination as a tool to empirically measure coherence.

In addition, there is also a need to distinguish between vertical, institutional (inter-institutional, intra-institutional) and external dimensions of coherence.

Vertical coherence refers to the matching of EU member state positions and policies with and in respect of the overall consensus or common position at the EU level (Gebhard 2011). This includes general compliance of member states with political commitments laid down in the treaties and also the technical compatibility of specific national policies with EU common policies. Incoherence at the vertical level rises due to the contradictions between the actions of EU institutions and the actions of EU member states.

Institutional coherence has two types of challenges: inter-institutional and intrainstitutional coherence. Inter-institutional incoherence is related to the tensions between different EU institutions: e.g. between the European Commission and the EEAS or between the Commission and the Council of the EU, whereas intrainstitutional incoherence refers to the tensions between the different branches of an institution-for instance between different Directorates General of the European Commission or between its political and administrative levels (Marangoni and Vanhoonacker 2015, 5).

External coherence refers to the EU capacity to present itself to third parties as a unitary actor and to the way the third parties perceive its actions (Gebhard 2011, 9). External coherence is primarily concerned with the functionality and credibility of the EU, rather than with specific foreign policy contents. External coherence is a function of vertical and horizontal dimensions of coherence because any failure to coordinate positions within the EU-either among the member states or between the institutions, might have a significant negative impact on EU ability to perform towards the third parties.

Without neglecting the role of the member states in EU crisis management, the paper narrows down its focus of the actors to supranational institutional agents addressing the inter-institutional dimension of coherence. Since the establishment of the European Security Defense Policy (ESDP) new diplomatic 
and military bodies such as the EU Special Representative (EUSR), Political Security Committee (PSC), EU Military Committee (EUMC), EU Military Staff (EUMS), Committee for Civilian Aspects of Crisis Management (CIVCOM) have been established in Brussels changing the nature of EU crisis management (Vanhoonacker, Dijkstra and Maurer 2010, 9). Thus, the EU crisis decisionmaking process can no longer be seen as a purely intergovernmental process of cooperation where the decisions are made in national capitals. The institutionalization of EU crisis management has altered the competences of EU institutions and created opportunities for them to possess a certain level of autonomy (Dimitrakopoulos 2001, 110). The latter means that institutions do not always act in a manner that complies with the initial wishes of member states. In the light of the inability of the member states to foresee all contingencies, institutions can become the actors with their own preferences and tend to pursue a power maximizing strategy which usually creates information asymmetries between the institutions and member states (Puchala 1999,318). For instance, an institutional agent may possess a private information on the ongoing peace negotiations in which it is representing the member states, to influence the crisis decision-making process (Puchala 1999,318). Therefore, it becomes relevant to observe the inter-institutional dimension of coherence in the context of EU crisis management and assess its influence on the coherence of crisis decision -making process

\section{4. "COHERENCE" IN THE CONTEXT OF BUREAUCRATIC POLITICS}

Observing the impact of institutional mandate overlaps on the coherence of EU crisis management the paper points to the crucial role of bureaucracies in EU foreign policy.

The EU is the most developed example of a multi-level governance system (Kohler-Koch and Jachtenfuchs 1996, Jachtenfuchs 2001). Its member states are no longer the only ones at the center of policy-making (Vanhoonacker, Dijkstra 
and Maurer 2010, 13). Policy is formulated and implemented through an interaction between different levels of public authorities. In this context, the EU institutional agents or supranational bureaucracies are considered as legitimate actors of EU multi-governance system, whose primary function is to plan and implement its policies.

Studying the bureaucratic apparatus of EU crisis management is primarily associated with the important role of bureaucracies as key actors shaping the nature of crisis policy planning and implementation (Moe 1990, 143). Since the creation of the Common Security Defense Policy (CSDP) in 1999 the EU crisis management has been marked by the overlapping mandates across multiple bureaucratic structures (Juncos 2013, 13). This fragmented nature of EU crisis management has strengthened the influence of bureaucracies on the nature of EU crisis decision making process and underlined the necessity to understand the causal link between the mandate overlaps and coherence, which is well described in the prism of "bureaucratic politics" theory: bureaucracies compete to extend their policy "turf" in the areas of their assigned responsibilities (Juncos 2013, 13).

The "bureaucratic politics" defines bureaucracies as hierarchical organizations jealously competing with each other to protect their own "turf" or preferences (Downs 1967, Alison and Halperin 1972). The preferences of bureaucracies are aligned with their mandates or functional roles. Thus, in order to fulfill their mandates, they seek to expand certain resources such as funding, decisionmaking discretion and political support (Kozak 1988, 5-10). Bureaucracies are engaged in the competitive struggle for the limited resources within a single policy area. The competition among bureaucracies occurs in the areas of overlapping responsibilities or mandates when two or more bureaucracies try to assert a permanent control over the same mandate (Holden 1966, 947). When the mandates of multiple bureaucracies operating within a single policy area are overlapped, it becomes difficult for them to act collectively and a further coordination is needed to enhance the coherence of their actions.

In the context of "bureaucratic politics" the EU supranational institutions or bureaucracies are seen as collective rational entities pursuing institutional 
preferences while seeking to maximize autonomy and avoiding time-consuming and resource-intensive coordination (Alison and Halperin 1972, 75).

The overlap of the mandates occurs as a result of not sufficient allocation of functional responsibilities among the EU institutional agents subject to similar commitments in the same policy area (Hofmann 2010, 104). The overlapping of the institutional mandates and resource scarcity trigger the inter-institutional competition and increase the necessity for coordination. Competition increases when a new bureaucratic institution invades the functional area of the territorial zone of the established actor(s) within a single policy space (Peters 2009,214). However, given the fact that the resources are limited and the agents have interrelated mandates, the tendency of each agent to increase its territorial zone at the expense of other agents territory will not be welcomed these agents. They will tend to jealously guard their territory and defend their turf (Hill 2003, 92). The latter will generate conflicts between the agents, creating a dysfunctional coordination (Downs 1967, Hill 2003). Coherence is directly affected by poor coordination, as it is defined as a well coordinated process of crisis decision making process (Christiansen 2001,747).

The below rectangle illustrates a single policy area (e.g. Mediation) within which multiple supranational agents are functioning. For simplicity only two institutional agents: the EU Special Representative and the Head of the EU Monitoring Mission (EUMM) are shown. Each actor operates within the boundaries of its functional responsibilities or mandates, which are defined as territorial zones. However, the overlap of their mandates causes tensions, when each actor competes to expand its mandates at the expense of other actor's mandates (Downs 1967, 26). This creates a dysfunctional coordination and impedes coherence. 


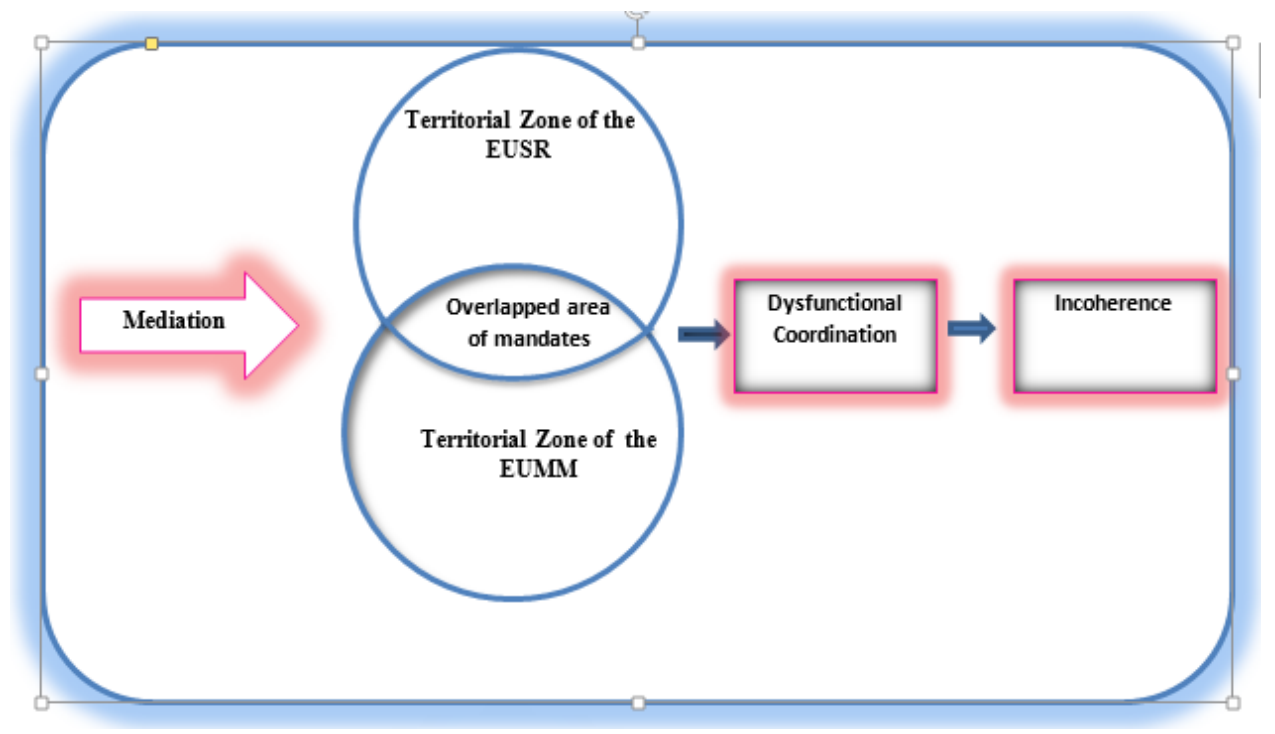

Coherence is assessed at nominal level, which means, if the overlap of mandates is coordinated by applying the necessary coordination mechanisms, then the crisis decision-making process is considered coherent, and if the overlap of mandates is not coordinated through the coordination mechanisms, the crisis decision-making process is considered incoherent.

The paper applies the linear method of causality to illustrate the link between dependent (coherence), independent (overlap of mandates) and intervening (coordination) variables, as the sequence of their interaction has a linear pattern: the overlap of mandates directly creates a need for coordination and the application or non-application of coordination procedures impacts the dependent variable-coherence.

\section{METHODOLOGY}

By addressing the incoherence of the EU crisis management in South Ossetia the research concentrates on the responses of EU institutional agents in charge of 
planning and implementation of EU crisis management activities in South Ossetia. The selection of institutional agents logically flows from the theoretical framework (bureaucratic politics paradigm), which considers the EU's institutional agents or supranational institutions as relevant players in the EU crisis decision-making process (Delreux 2015, 6-8). Here the focus lies on the reaction of specific analytical units (institutional agents) to the escalation of the South Ossetian conflict.

The research extends to the following policy areas of EU crisis management: Common Foreign Security Policy (CFSP) and Development Aid Policy. These two policy areas are at the core of the EU coherent approach to crisis management as outlined in the European Security Strategy (European Council 2003,2) and in a recent Commission Joint Staff Working Document on taking forward the EU's Comprehensive Approach to external conflicts and crises (European Commission 2013). In addition, the EU has been engaged in the South Caucasus applying its short term and long-term crisis management tools. Short term responses refer to CSDP crisis management instruments and crisis response measures under the Instrument for Stability (IfS), whereas the development instruments such as post-conflict rehabilitation and development assistance activities are oriented towards the long term crisis management objectives (European Commission 2013,8).

The data collection includes the primary and secondary sources which helped to trace the EU crisis response cycle in the planning and implementation levels of EU crisis management, identifying the main policy documents and mandate implementation reports.

However, the interviews were of particular relevance for the analysis of EU crisis decision-making process, as an additional "insider" knowledge was required which could not be obtained only through document analysis and the access to some EU internal policymaking documents was often limited. The research relies on thirteen semi-structured interviews conducted with the EU officials from the Commission (DG DEVCO, DG NEAR, FPI), the EEAS (CMPD, CPCC, CIVCOM), the EUSR Administration and the EU Monitoring Mission in Georgia in June 2016 and April 2018. The objective of semi-structured interviews was to capture the interviewee`s personal point of view and to allow him or her to talk freely in 
order to offer a his/her interpretation of a certain event or issue. The interviewees were asked specific questions from the same theme; however, the semi-structured format of interviews allowed the respondensts to provide open answers.

\section{BACKGROUND OF THE CONFLICT}

The conflict over South Ossetia erupted when the Soviet Union fell apart and Tbilisi's claim for territorial integrity versus the national self-determination claimed by the Ossetians could no longer be reconciled within the disintegrating empire (Ratliff 2006). Georgia wanted to maintain its territorial integrity and prevent South Ossetia from seceding. While South Ossetia wanted to either gain independence from Georgia and to join North Ossetia (Ratliff 2006). Subsequently, South Ossetians not only boycotted the political process in Georgia, including the September 1990 elections, but also declared their region's independence (Wolff 2011). In 1991 the hostilities escalated, leading to the Georgian occupation of South Ossetia's capital, Tskhinvali. Both sides suffered considerable military and civilian losses. The war over South Ossetia lasted until June 1992 leading to about 1,000 casualties and from 60,000 to 100,000 internally displaced persons (IDPs) and refugees fleeing to Georgia and North Ossetia (Merlingen and Ostrauskaite 2009, 4-9). A ceasefire was established between the Russian President Boris Yeltsin and the Georgian President Eduard Shevardnadze in the frameworks of the Sochi Agreement in 1992 (Merlingen and Ostrauskaite 2009). This was followed by the deployment of an OSCE Observer Mission and a Russia-led Commonwealth of Independent States'(CIS) peacekeeping force, as well as the creation of the so-called Joint Control Commission(JCC) which aimed to facilitate cooperation between Georgia and South Ossetia on a day-to-day basis(Merlingen and Ostrauskaite 2009). The JCC comprised of Russian, Georgian and Ossetian troops, in which the European Commission had been granted an observer status since 2000.

In 2006 Georgia`s motivation to join the North Atlantic Treaty Organization (NATO), further aggravated the relations between Russia and Georgia. On 7 
August 2008, Georgian troops entered South Ossetia through the Roki tunnel shelling its capital Tskhinvali.

Eventually, the leadership role in the mediation of South Ossetian conflict was assumed by France, which held the EU Presidency. President Nicolas Sarkozy and Foreign Minister Bernard Kouchner traveled to Tbilisi and Moscow, where they mediated a six-point ceasefire agreement (Isakhanyan 2011). In late 2008, the Geneva Talks on security and stability were launched, bringing together the representatives of Tbilisi, Moscow and South Ossetia co-mediated by the EU, UN and OSCE (Grono 2010, 24).

\section{THE EU'S RESPONSE TO THE SOUTH OSSETIAN CONFLICT}

The EU engagement in South Ossetia is analysed in two time periods. The first period is associated with the gradual thawing of the conflict beginning in 2003, and the escalation of hostilities when Georgian troops entered South Ossetia and occupied its capital, Tskhinvali, in August 2008. During the 2003-2010 period, the EU expanded its Common Foreign Security Policy (CFSP) tools through the EU Special Representative (EUSR) mandate in the South Caucasus, in addition to serving as an observer in the Joint Control Commission (JCC), co-chairing the Geneva Talks together with the United Nations (UN) and the Organization for Security and Cooperation (OSCE) and deploying an EU Monitoring Mission (EUMM) in the region.

The second period is from 2010 to 2013, when there was no direct violence in the region and the climate of tension had declined. As a result of the 2010 Lisbon Treaty, the EU expanded its crisis management activities in the region and introduced new actors, attempting to improve coherence in crisis management by creating the position of High Representative (HR), a Security Policy and Conflict Prevention (SECPOL) Unit within the newly established European External Action Service (EEAS). 
After establishing the Six Point Ceasefire Agreement initiated by the EU between Russia and Georgia in 2008, the Geneva Talks or Geneva International Discussions (GID) were launched in October of that year (Phillips 2011,11), bringing together representatives of Georgia, Russia and South Ossetia, and cochaired by the EU through the EUSR, the UN and the OSCE. The Geneva Talks were intended to discuss security and stability arrangements in the region and the situation of Internationally Displaced Persons (IDPs) and refugees, as well as any other subject brought up by mutual agreement between the parties.

The EU also launched an unarmed civilian EU Monitoring Mission (EUMM) to Georgia (EEAS 2010) in October 2008. The EUMM's deployment was the fastest mission deployment in EU history. The mission set out to monitor the actions of Georgia and South Ossetia and their full compliance with all six points of the Agreement and to contribute to stabilization, normalization and confidence building among the relevant authorities on the ground (EEAS 2010).

During the planning stage of the EU Monitoring Mission (EUMM), the rapid EU response to the escalation of the conflict between Russia and Georgia in 2008 was accompanied by the overlapping responsibilities of the two main institutional actors located in Brussels: the Directorate for Crisis Response and Operational Coordination (CROC) and Civilian Planning Conduct Capability (CPCC). Both the DG CROC and the CPCC were mandated to work together to draft the mission's operational plan and its main features. Each of these actors sent its own team to the field to collect information which would set the stage for the EUMM (EU Official 2018). This deployment of multiple exploration teams with similar tasks made it difficult to coordinate the mission's planning process. Based on the "bureaucratic politics" theoretical framework, the overlap of the DG CROC and CPCC mandates in the absence of coordination mechanisms has contributed to an incoherent crisis decision-making process.

In addition to its responsibility for the operational planning of the mission, the DG CROC was mandated to coordinate all phases of the Crisis Response Cycle by identifying the appropriate tools and instruments available at the EU level (Tercovich 2014,3). The coordination of the humanitarian aid monitored by the DG CROC was also carried out by the European Civil Rights Protection and Humanitarian Aid Operations (ECHO) which had a similar mandate regarding 
the immediate EU responses to disasters (Tercovich 2014,3). This situation created an additional layer of tension between the EEAS and the Commission. To avoid future overlap, it was decided to dissolve the DG CROC in 2012 by transferring the staff with experience in working on political crises to the Directorate for Security Policy and Conflict Prevention (SECPOL) and those dealing with the humanitarian aspects of crises to DG ECHO. Eventually the mandate for the coordination of the whole crisis response cycle became the responsibility of the HR (EU Official 2018).

A particularly confusing situation arose concerning the mandates of the two EU Special Representatives (EUSRs) engaged in the South Caucasus after the RussiaGeorgia war. The EUSR Peter Semneby had been the EUSR for the South Caucasus region since 2003. However, a French diplomat named Pierre Morel, who had been the EUSR for Central Asia, was appointed as an additional EUSR for the crisis in Georgia on September 1, 2008 (EEAS 2016). This was illogical, as Morel was mandated to contribute to the strengthening of democracy, the rule of law, good governance and respect for human rights and fundamental freedoms in the Central Asian countries concurrently to his appointment as the EUSR for the crisis in Georgia with an additional mandate (Popescu 2011,89). As a result, Morel's appointment as the EUSR for the Crisis in Georgia in the wake of the war in August 2008 overlapped with the responsibilities of the acting EUSR of the South Caucasus, Peter Semneby, delineating his mandate to conducting mediation and political dialogue. Semneby still remained the EUSR for the South Caucasus, but his Georgia-related responsibilities were trimmed (EU Official 2018). During the coexistence of the two EUSRs, overlaps in their mandates stretched existing resources and caused tensions between them (EU Official 2018). For instance, in accordance with his mandate, Semneby could participate in political dialogues at the Geneva talks, as could the second EUSR, Morel (EU Official 2018). However, EUSR Semneby was neither authorized to act as the mediator between the parties in the conflict within the framework of Geneva Talks, nor given any strong material leverage to exert influence on Georgia and South Ossetia (Hughes 2010, 103). Instead, Semneby was more involved in political groundwork with the EUMM via engaging domestic players on the ground (Hughes 2010, 103). 
Semneby's absence in the Geneva Talks created the need to coordinate the EUSRs' activities as, in many cases, neither EUSR was aware of the other's activity on the ground (EU Official 2018). On several occasions, both EUSRs went into the field to conduct the same confidence-building activities without informing each other (EU Official 2018). This situation made coherent implementation of the political dialogue and mediation activities between Georgia and South Ossetia problematic, as the overlapping of the two EUSRs' mandates was not coordinated.

In relation to the Development Aid Policy, the EU has assisted South Ossetia with post- conflict rehabilitation aid programs since 2003. In January 2004, the Joint Control Commission (JCC) signed a protocol for the implementation of a Commission-funded rehabilitation program in the Georgian-Ossetian conflict zone (International Crisis Group 2004, 3-4). A Steering Committee comprised of representatives from the Commission and the Georgian and South Ossetian governments, was set up under the JCC to address the technical aspects of the project`s implementation.

The European Commission has become the biggest international donor in South Ossetia since 2006, considerably intensifying its crisis management activities (EU Delegation to Georgia 2009, 1). With the launch of the Instrument for Stability (IfS) in 2007 as a follow-up to the Rapid Reaction Mechanism (RRM), the Commission began financing more projects. The projects financed under the IfS aimed to improve the living conditions of the local populations that suffered the consequences of the conflict and to create conditions for the return of IDPs who had to flee their homes in the early 1990s.

In the post-Lisbon era, the EU has been more engaged in the implementation of post-conflict rehabilitation projects, facilitated by a reliance on the Instrument Contributing to Stability and Peace (IcSP) (European Commission 2011,1). In May 2010, the Commission began funding confidence building and dialogue programs in South Ossetia under the name "Confidence Building Early Response Mechanism (COBERM) (Commission Staff Working Document 2013, 17). The COBERM included small-scale projects between communities in Georgia and South Ossetia, with the main objective of fostering a peaceful transformation of the conflicts and promoting person-to-person contact (Jeppson 2015, 14). 
As regards the mandate overlaps in relation to Development Aid Policy, at the planning phase of Commission-funded rehabilitation projects in 2004, such as electricity and gas supply to Gori and adjacent areas of South Ossetia, there were no cases of inter-institutional mandate overlap, as only the DG for External Relations (RELEX) was involved in the planning phase and the Organization for Security and Co-operation in Europe (OSCE) carried out the implementation (EU Diplomat 2018).

Similarly, DG RELEX did the planning of the first phase of the Commissionfunded small-scale confidence building projects in South Ossetia, under the strategic guidance of the Political Security Committee (EU Official 2018) from 2008 to 2009. However, the electricity and gas projects planned for 2008, as well as the economic rehabilitation programs in Georgia and South Ossetia, were soon suspended due to the Russia-Georgia war (EU Official 2018).

The second phase of the Instrument for Stability (IfS) project, including the development of an early warning system in the Shida Kartili region of South Ossetia, was also planned by DG RELEX and implemented by the United Nations Development Program (UNDP); no other institutional actor was involved in that planning process (EU Official 2018). Thus, due to the presence of only one institutional actor, DG RELEX, there were no mandate overlaps.

Since the Lisbon Treaty, the EU has been engaged in South Ossetia through postconflict rehabilitation projects under the Confidence Building Early Response Mechanism (COBERM) and the IfS.

The first project funded in South Ossetia under COBERM was Engagement through Dialogue: Dialogue and Study Visits for the Management of the Georgian-Ossetian Conflict (Commission Staff Working Document 2013, 17). The project planning was a joint effort by the EEAS Conflict Prevention and Security Policy (SECPOL) unit and the Commission Foreign Policy Instruments (FPI) unit. The UNDP implemented the project in the field, in cooperation with the EU Delegation in Georgia.

Disputes between the SECPOL and the FPI on the programming and financing of the project were not uncommon at the onset of the programming process. There seemed to be a lack of interaction between the SECPOL and the FPI. An interviewee mentioned the need for these two actors to exchange information 
(EU Official 2018). In fact, before the Lisbon Treaty, it was the DG RELEX within the Commission, which dealt with all the programming of external policies and bringing together all portfolios related to EU crisis management. The DG RELEX served as a forum for discussing all relevant issues related to the programming and implementation of EU crisis management policies (EU Official 2018). After the Lisbon Treaty, in addition to dealing with intra-institutional coherence, the Commission had to coordinate its activities with a newly created institutional actor, EEAS, as the latter took over DG RELEX functions and DG Development political desks, as well as programming aspects (Duke 2011,43).

Furthermore, the EEAS was granted coordinating function and participation in the programming and management cycle for financial instruments, together with the newly created Europe Aid Development and Cooperation DirectorateGeneral (DEVCO) within the Commission (Duke 2011, 26). Thus the programming of EU crisis management projects related to development aid must be done in close coordination with the Commission, since the thematic instruments still remain within the Commission.

According to the source from EEAS, the FPI and SECPOL were reluctant to cooperate, each of them pursuing its own agenda regarding the launching of the first COBERM project in South Ossetia. In addition, the SECPOL did not receive the COMDEL meeting minutes and was not consulted on relevant FPI and EU Delegation initiatives in the field (EU Official 2018). Consequently, the extent to which information was exchanged between the SECPOL and the FPI appeared limited and the overlap of their mandates continued without further coordination, negatively affecting the coherence of the project planning process, which confirms the main argument of this paper (EU Official 2018).

During 2011-2012, the Commission funded the rehabilitation of water-related infrastructure in the Zonkari Dam (Commission Staff Working Document 2013, 17). The project was planned by the FPI, and the EUSR team was also closely involved in the process, as it was the EUSR's idea to fund the project (EU Official 2018). The FPI analysed the feasibility of the proposal and agreed to fund it through the IfS. However, there was no overlap between the mandates of the FPI and the EUSR administration because their tasks were clearly defined: the FPI 
was responsible for the management of the project's budget and the EUSR was dealing with its strategic planning.

Immediately after the implementation of the water infrastructure repair project at the Zonkari Dam, another project providing potable water to households living next to South Ossetia's Administrative Boundary Lines (ABLs), mainly in Znauri and Nikosi, was supposed to be implemented (EU Official 2018). The project was planned by the Commission's FPI unit and implemented by the EU Delegation in Georgia. At the planning stage of the project the interviewees from the EEAS and Commission did not confirm any cases of mandate overlaps because only the FPI was involved in the entire planning process. Meanwhile, at the implementation level a similar water irrigation confidence-building project was conducted by the EUMM in Znauri and Nikosi with a $€ 200,000$ budget (EU Official 2018). Both projects aimed to enhance the confidence building between Georgia and South Ossetia. However a simultaneous implementation of the two projects could cause overlap of the mandates between the Heads of the EUMM and the EU Delegation to Georgia and delay the implementation of both projects(EU Official 2017). For that purpose a small coordination committee comprising of the EUSR, the Head of the EUMM and the Head of the EU Delegation was established in 2012, concurrent with the initiation of the newly appointed Head of the EUMM, Andrzej Tyszk (EU Official 2017). The Committee meetings were held informally and were organised by the EUMM project manager. This newly established informal coordination mechanism improved the information sharing between the EU Delegation in Georgia and the EUMM on the ground.

\section{CONCLUSIONS}

The overview of this paper indicates that the EU has shown considerable interest in the South Caucasus since 2003, clearly identifying its economic and security goals in the region. The EU began enriching its toolbox of crisis management capabilities to be better prepared for involvement in the region as a crisis manager. 
The EU has been praised for its spontaneous engagement in the South Ossetian conflict in several instances (EU Official 2018). EU involvement in the region has taken the form of direct intervention in the conflict, covering the activities which fall under the Common Foreign Security Policy (CFSP) policy area, such as CSDP fact-finding, civilian missions, confidence building and mediation efforts, as well as activities in the area of development aid such as Commission-financed postconflict reconstruction and rehabilitation measures. However, these achievements have been blurred with incoherent decision-making processes at both the planning and implementation phases of EU crisis management. As cited by an EU official, the EU had already managed to develop a complex institutional framework by 2003, creating multiple crisis management mechanisms such as the European Security and Defence Policy (ESDP), new diplomatic and military bodies (including the EU Special Representatives (EUSR), the Political Security Committee (PSC), the EU Military Committee (EUMC), EU Military staff (EUMS) and the Committee for Civilian Aspects of Crisis Management (CIVCOM). And the more EU actors are involved in the specific policy area, the greater the potential for the EU to become engaged in multiple areas of crisis management; however, such intervention further complicates (and can limit) the ability of EU institutional actors to effectively coordinate their actions (Faria 2014, 13). This is especially challenging when different institutional actors have overlapping competences and different reporting channels and there is no 'control and command' structure that clarifies who speaks for the EU (Faria 2014, 13). The case of the EU's engagement in South Ossetia has been one excellent example of all those challenges combined.

The analysis of EU activity in South Ossetia has shown that the overlap in institutional mandates started after the outbreak of the Russia-Georgia war in 2008 when the institutional framework of EU crisis management in Georgia became a very crowded arena with multiple actors using different management methods, varying according to their mandates.

At the planning level, the existence of the Crisis Response and Operational Coordination (CROC) Department created duplications and tensions with the Civilian Planning Conduct Planning Capability (CPCC), which was traditionally mandated to coordinate the operational planning of civilian CSDP missions. An 
interviewee mentioned that, in the absence of direct lines of reporting between the DG CROC and CPCC at the planning phase, these two actors had a great deal of difficulty sharing information (EU Official 2018).

The EU Monitoring Mission (EUMM) was heavily involved in normalization at the field level, coordinating stabilization and confidence building activities across South Ossetia through the framework of the Incidence Prevention Response Mechanism (IPRM). The EU Special Representative (EUSR) for the Crisis in Georgia was engaged in political dialogue in the context of the Geneva Talks, while the EUSR for the South Caucasus was also very active on the ground until his mandate ended in February 2011. Consequently, the two similar mandates did not support of one another - they actively clashed, indicating a lack of coordination.

In fact, in some cases EU institutional agents' mandates might seem to be broadly defined on paper, but can cause considerable confusion with each other (EU Official 2018) in practice. For instance, the EUSR's broad mandate to the South Caucasus and Crisis in Georgia involved contributing to a peaceful settlement of the South Caucasus conflicts, including Georgia's conflicts in Abkhazia and South Ossetia and the Nagorno-Karabakh conflict, and encouraging regional cooperation (Jeppson 2015). The EUSR was additionally mandated to co-chair the Geneva Talks, representing the EU, and to facilitate the implementation of the ceasefire agreements. Thus, there was a confusion about institutional roles and no adequate inter-institutional division of labor was applied. This contributed to a sense of competition and a lack of coordination between the two EUSRs in the South Caucasus, which made the mediation process incoherent (EU Official 2018).

A deeper strategic coordination of efforts by the two EUSRs was needed to regulate the overlapping areas of their responsibilities, which would facilitate information exchange and joint work between the two actors (EU Official 2018). However, due to the absence of such a coordinating mechanism between the two EUSRs, the overlap in their mandates continued until the two were merged (EU Official 2018) in September 2011.

As regards the overlap in EEAS Conflict Prevention and Security Policy unit (SECPOL) and Foreign Policy Instrument Service (FPI) mandates, the EEAS and 
the Commission have established formal working agreements to coordinate their activities(European Commission 2012,15). Unfortunately, the new formal procedures are more confusing and more demanding overall than those that existed when the DG RELEX oversaw EU external relations, because the EEAS is now separated from the Commission (European Court of Auditors 2014,15). In addition, according to an EEAS interviewee, the establishment of the EEAS as a separate entity has increased the number of EU institutions dealing with the same issues. One such instance is the programming of EU civilian crisis management activities for development aid, which were formerly planned by only one actor - DG RELEX (EU Official). In the post-Lisbon era the FPI and SECPOL undertake that task. Because the FPI is physically located within the EEAS, the tensions between the Commission and EEAS still remain unresolved (EU Official 2018). In fact, there is no official document providing a clear division of labor between the Commission and the EEAS, and the effectiveness of information exchange is based on ad hoc, informal communication (EU Official 2018).

In order to prevent future inter-institutional overlaps between the Commission and EEAS, the High Representative (HR) should also increase her presence and leadership in promoting inter-institutional coherence of EU crisis management, as the key function of the HR is to ensure the coherence of external EU actions (Blockmans and Wessel 2009, 42). In the early 2010s, the South Caucasus region was not in the domain of the HR; moreover, she intended to abolish the EUSR mandate with the aim of retaining the EUSRs only for the Great Lakes area and Central Asia, because the Lisbon Treaty gave her more influence on the nomination of EU Special Representatives (EUSRs). Whereas the Political Security Committee (PSC) is mandated to appoint a EUSR "whenever it deems it necessary", the HR alone is mandated to appoint a new EUSR (Tolksdorf 2012, 2).

Furthermore, the HR's dual function in the Commission and Council did not guarantee coherence on intra- institutional level because she was absent from most of the Commission meetings related to Development Aid (EU Official 2018). This limited her overall capacity to ensure smooth inter-institutional coordination between the Commission and EEAS (EU Official 2018). The HR 
should increase her presence in the Commission and conduct regular stakeholder meetings (FPI, SECPOL) dealing with the planning of development aid programs in the South Caucasus. This would enhance inter-institutional coordination and increase the potential for the EU to eliminate the existing gap between the EEAS and Commission.

In fact the Treaty of Lisbon provided the HR with the task of ensuring coherence in the EU`s external relations, as mentioned in Article 9 of the treaty, but it did not provide specific guidelines on how the HR should execute this task (EU Official 2018).

Moreover, the treaty did not specify the EEAS institutional structure under the HR's leadership or how the newly created EEAS should interact with the Commission, taking into consideration the fact that the Commission still administers the CFSP budget and the main thematic instruments, such as the Instrument Contributing to Stability and Peace (IcSP), the EU Development Fund (EDF), and the European Neighborhood and Partnership Instrument (ENPI).

Thus, there is a need to strengthen internal institutional cooperation at both the horizontal and vertical levels to achieve a coherent crisis decision-making approach to external conflicts. In order to achieve this objective, the formal division of labor between the different institutional agents, including relevant policy-making and implementation mandates, must be clearly defined on paper. Furthermore, the implementation of institutional mandates should be followed by establishment of clear coordination mechanisms at both the planning and implementation phases of decision making in the two separate policy areas of EU crisis management: CFSP and Development Aid Policy. As Mahncke $(2013,37)$ mentioned the Lisbon Treaty provided a new inter-institutional structure by creating the EEAS mandate and introducing new institutional actors. It is now up to the institutional actors to cooperate with the aim of establishing a coherent policy. 


\section{REFERENCES}

- Blockmans, Steven and Wessel, Ramses. 2009. "The European Union and Crisis Management: Will the Lisbon Treaty Make the EU More Effective?" Journal of Conflict and Security Law 14. No.2: 265-308.

- Christiansen, Thomas. 2001. "Intra-Institutional Politics and InterInstitutional Relations in the EU: Towards Coherent Governance?" Journal of European Public Policy 8, No.5:747-769.

- Commission Staff Working Document. 2014. Annual Report on the Instrument for Stability, SWD 344. http://eeas.europa.eu/ifs/docs/comm_staff_work_doc_2013_vol2_en.pdf.

- Consolidated Versions of the Treaty on European Union and the Treaty on the Functioning of the European Union.2012. Article 21, 2012/C 326/01. https://eurlex.europa.eu/legalcontent/EN/TXT/HTML/?uri=CELEX:1201 2M/TXT\&from $=\mathrm{EN}$.

- Cremona, Marise. 2011. "Coherence in European Union Foreign Relations Law, Edited by Panos Koutrakos", European Foreign Policy: Legal and Political Perspectives, Edward Elgar, Cheltenham.

- Delreux, Tom. 2015. "Bureaucratic Politics, New Institutionalism, Principal Agent Models". Edited by Wahl Jorgensen, Aasne Aarstad, Edith Driekens, Katie Laatikainen and Ben Tonra, in The SAGE Handbook on European Foreign Policy, London, SAGE: 152-165.

- Dimitrakopoulos, Diagnosis. 2001. "Unintended Consequences: Institutional Autonomy and Executive Discretion in the European Union", Journal of Public Policy 21, No.2: 107-131.

- Downs, Antony. 1967. Inside Bureaucracy. Boston: Little Brown and Company.

- Duke, Simon. 2011. "Consistency, Coherence and European Union External Action: the Path to Lisbon and beyond". edited by Panos Koutrakos, European Foreign Policy: Legal and Political Perspectives. Edward Elgar. Cheltenham.

- European Commission. 2011. Annual Report on the Instrument for Stability, (SWD) 225 final. https://eeas.europa.eu/ifs/docs/ifs_annual_report_2011_en.pdf.

- European Commission. 2013. EU`s Comprehensive Approach to External Conflicts and Crises. Joint Communication to the European Parliament and the 
Council. JOIN 30 final. https://eur-lex.europa.eu/legalcontent/EN/TXT/PDF/?uri=CELEX:52013JC0030\&from=EN.

- European Commission, Secretarial General. 2012. Working Arrangements between Commission Services and the European External Action Service (EEAS) in Relation to External Relations Issues. SEC 48. http:/ / ec.europa.eu/transparency/regdoc/rep/2/2012/EN/2-2012-48-EN1-1.PDF.

- European Court of Auditors. 2014. The Establishment of the European External Action Service. Special Report. https://www.eca.europa.eu/Lists/ECADocuments/SR14_11/SR14_11_EN. pdf

- European Movement International. 2016. The European Union's Role in Providing Peace and Security: Challenges for the New EU Team: 1-4. http:// europeanmovement.eu/wp-content/uploads/2015/05/FA-2014Peace-and-Security-ADOPTED.pdf.

- European Union Delegation to Georgia. 2009. Overview of EC Assistance to People Affected by Conflict in Georgia.

- European Union External Action Service (EEAS). 2004. EU-Georgia Action Plan. https://eeas.europa.eu/sites/eeas/files/georgia_enp_ap_final_en_0.pdf.

- European External Action Service (EEAS). 2010. European Union Monitoring Mission in Georgia (EUMM). https://www.eumm.eu/en/about_eumm.

- European Union External Action Service (EEAS). 2016. Formal Special Representatives.

http:/ / eeas.europa.eu/background/eu-special-representatives/formerspecial-representatives/index_en.htm.

- European Union Monitoring Mission (EUMM) in Georgia. 2013. Press Communique of the Co-Chairs of Geneva Discussions, Press and Public Information Section, Tbilisi. http://eumm.eu/en/press_and_public_information/press_releases/3896/.

- Faber, Jan. 2000. "Cold Wars and Frozen Conflicts: The European Experience", edited by Mary Kaldor, 56, Global Insecurity. London: Wellington House.

- Faria, Fernanda. 2014. "What EU Comprehensive Approach? Challenges for the EU Action Plan and Beyond". European Centre for Development Policy Management. Briefing Note No.71: 1-18. 
- Gebhard, Carmen. 2008. "EU Crisis Management from an Institutional Perspective". Paper presented at the European Consortium for Political Research: $1-44$.

https://ecpr.eu/Filestore/PaperProposal/ce69c547-1be6-448e-bada3b4b147e859c.pdf.

- Graham, Alison and Morton, Halperin. 1972. "Bureaucratic Politics: A Paradigm and Some Policy Implications". World Politics Vol. 24, Supplement Theory and Policy in International Relations, Cambridge University Press.

- Grono, Magdalena. 2010. “Georgia`s Conflicts. What Role for the EU as a Mediator? Initiative for Peacebuilding", (IFP) Mediation Cluster, International Alert: 1-40. http://georgica.tsu.edu.ge/files/05-Security/Frichova-2010.pdf.

- Hill, Christopher. 2003. The Changing Politics of Foreign Policy. Houndmill, Basingstoke. New York: Palgrave Macmillan.

- Hofmann, Stephanie. 2010. “Why Institutional Overlap Matters?". Journal of Common Market Studies 49, No. 1.

- Holden, Matthew. 1966. "Imperialism in Bureaucracy". American Political Science Review, No.60: 943- 951.

- Hughes, James. 2010. "EU Conflict Management". Ethnopolitics. Routledge.

- International Crisis Group Georgia. 2004. "Avoiding War in South Ossetia" Europe Report. No. 159. Tbilisi/Brussels: 1-44. https://www.icccpi.int/RelatedRecords/CR2015_19452.PDF

- Isakhanyan, Levon. 2011. EUMM - Georgia: the European Union Monitoring Mission. http://www.diploweb.com/EUMM-Georgia-the-EuropeanUnion.html

- Jeppson, Emilia. 2015. “A Differentiated, Balanced and Patient Approach? The EU's Involvement with Georgia's Secessionist Conflicts beyond the August 2008 War". College of Europe, EU Diplomacy Paper No.6. https://www.coleurope.eu/.../edp_6_2015_jeppsson_0.pdf?...1

- Juncos, Ana. 2013. EU Foreign Policy and Security in Bosnia. Manchester: University Press.

- Kakachia, Kornely. 2011. "Challenges to the South Caucasus Regional Security aftermath of Russian-Georgian Conflict: Hegemonic Stability or New Partnership?" Journal of Eurasian Studies. 2. No.1.:15-20.

- Kohler-Koch, Beate and Jachtenfuchs, Markus.1996. "Catching up with Change: The Transformation of Governance in the European Union". Journal of European Public Policy, No.3.:359-380. 
- Kozak, David. 1998. "The Bureaucratic Politics Approach: The Evolution of the Paradigm", edited by David Kozak and James Keagle, Bureaucratic Politics and National Security: Theory and Practice, Boulder, Co.: Lynne Rienner Publishers.

- Mahncke, Dieter and Gstöhl, Sieglinde, 2012, European Union Diplomacy: Coherence, Unity and Effectiveness. New York: Peter Lang.

- Marangoni, Anne-Claire and Vanhonacker, Sophie. 2015. "The Consistency of EU External Action Post-Lisbon: Renewing Appropriate Measures against Zimbabwe in 2012", European Integration online Papers (EIoP) 19. No. 3: 1-22.

- Merlingen, Micheal, and Ostrauskaite, Rasa. 2009. "EU Peacebuilding in Georgia: Limits and Achievements", Leuven Centre for Global Governance Studies, Working Paper, No. 35: 1-32. https://ghum.kuleuven.be/ggs/publications/working_papers/new_series /wp31-40/wp35.pdf

- Moe, Terry. 1990. "The Politics of Structural Choice: Towards a Theory of Public Bureaucracy", edited by Oliver Williamson, in Organisation Theory From Chester Bernard to the Present and Beyond, New York: Oxford University Press.

- Nagle, John and Clancy, Marie-Alice. 2001. "Frozen Conflicts. Minority SelfGovernance, Asymmetrical Autonomies", International Conflict Research Institute (INCORE), Ulster. http://www.asef.org/images/docs/12766th_AER_Background_Paper_-_Dr._Clancy_and_Dr._Nagle.pdf.

- Nuttal, Simon. 2001. "Consistency and the CFSP: a Categorization and its Consequences". European Foreign Policy Unit (EFPU), Working Paper Series, No.3.:1-10.

- Peters, Guy. 2009. The Politics of Bureaucracy: An Introduction to Comparative Public Administration, New York: Routledge.

- Phillips, David. 2011. Six Point Ceasefire Agreement between Russia and Georgia. The National Committee on American Foreign Policy: 1-30.

https://www.ncafp.org/2016/wpcontent/uploads/2011/08/Implementation-Review-Russia-and-GeorgiaAug20111.pdf.

- Popescu, Nicu. 2011. EU Foreign Policy and Stealth Intervention. Routledge.

- Portela, Clara and Raube, Kolija. 2012. "The EU Polity and Foreign Policy Coherence". Journal of Contemporary European Research, 8, No.1: 3-20. 
- Post, Svenja. 2015. Toward a Whole-of-Europe Approach: Organizing the European Union's and Member States' Comprehensive Crisis Management, Wiesbaden, Springer VS.

- Puchala, Donald. 1999. "Institutionalism, Intergovernmentalism and European Integration: A Review Article", Journal of Common Market Studies 37, No.2:317-331.

- Ratliff, Rebecca. 2006. "South Ossetian Separatism in Georgia". ICE Case Studies. http://mandalaprojects.com/ice/ice-cases/ossetia.htm.

- Tercovich, Giulia. 2014. "Towards a Comprehensive Approach: The EEAS Crisis Response System", Journal of Contingencies and Crisis Management, 22. No.3:1-8.

- Tolksdorf, Dominik. 2012. "The role of EU Special Representatives in the post-Lisbon Foreign Policy System: A Renaissance?" Policy Brief, Institute for European Studies, Vrije University Brussel :1-4.

- Jachtenfuchs, Markus. 2001. "The Governance Approach to European Integration", Journal of Common Market Studies, 39. No.2. 245-264.

- Vanhoonacker, Sophie, Dijkstra, Hylke and Maurer, Heidi. 2010. "Understanding the Role of Bureaucracy in the European Security and Defense Policy (ESDP)", European Integration online Papers (EIoP):1-33. http:/ / eiop.or.at/eiop/pdf/2010-004.pdf.

- Wolff, Stefan, 2011, Georgia: Abkhazia and South Ossetia, The Princeton Encyclopedia of Self-Determination. https://pesd.princeton.edu/?q=node/274. 